\title{
The Revitalization of Srimpi Muncar Dance Through Social Media in the Hyppereality-Post Truth Era
}

\author{
Risa Kaizuka ${ }^{1, *}$ Dr. Kuswarsantyo ${ }^{1}$ Andi Azri Nining Rukmana ${ }^{1}$ \\ ${ }^{1}$ Graduate School of Art Education, Yogyakarta State University, Yogyakarta, Indonesia \\ *Corresponding author. Email: risa.fr90@gmail.com
}

\begin{abstract}
This study aims to describe the revitalization of Srimpi Muncar dance through social media in the post-truth era of hyperreality. The researchers focused on the performance of Srimpi Muncar dance in Uyon-uyon Hadiluhung which was held live streaming from YouTube and Periscope accounts of Ngayogyakarta Hadiningrat Palace on August 10, 2020, in the midst of the Covid-19 pandemic. This study employed the qualitative research method with a phenomenological approach. Primary data were collected through documentation techniques with tables classifying comments given by the public to the palace social media accounts. Secondary data were obtained through interviews and consultation with supervisors. The data analysis was carried out in three stages, namely data reduction, data presentation, and conclusion drawing. In this study, the data reliability was checked using the data triangulation technique. The results show that the live streaming show of Srimpi Muncar dance is not hyperreality, because it has a positive impact. The social media accounts of the Yogyakarta Palace play an essential role in the revitalization of Srimpi Muncar dance. Social media is a new way to preserve Yogyakartan classical dance. This new strategy in performing shows is acceptable. It seems that traditional arts will not disappear with technological advances, but technology will be an aid for developing traditional arts nowadays.
\end{abstract}

Keywords: Revitalization, Srimpi Muncar, hyperreality, Simulakra, post-truth.

\section{INTRODUCTION}

Since the beginning of 2020, there has been an outbreak of Covid-19 (Coronavirus Disease 2019) around the world. This outbreak prohibits people to conduct events. The impacts of Covid-19 on the field of arts in Indonesia are felt by all studios and performing art event organizers. However, Covid-19 will not be stopped artists from carrying out activities. One prominent example of this special art activity during this pandemic situation is the online dance show by the Ngayogyakarta Hadiningrat Palace. Started from a virtual dance competition called Beksan Nir Corona which is conducted to celebrate the 32nd Mangayubagya Tingalan Jumenengan Dalem Sri Sultan Hamengku Buwana X, the Yogyakarta Palace tries to raise public attention to traditional arts. In this event, the palace keeps on educating people to keep on maintaining their health.

Social media played an important role in Srimpi Muncar dance show in the Uyon-uyon Hadiluhung event which was held on August 10, 2020. Uyonuyon Hadiluhung is an event held by the
Ngayogyakarta Hadiningrat Palace every Monday Pon night Tuesday Wage to commemorate Wiyosan Dalem/Sri Sultan Hamengku Buwana X birthday. During the pandemic situation, the event implemented health protocols and was held without reservation and audiences. Uyon-uyon Hadiluhung is a ceremony that is usually closed and performed only for guests. However, people all aroung the world can watch Uyon-uyon Hadiluhung via live streaming from YouTube and Periscope. Srimpi Muncar dance which had not been performed for a long time was shown virtually at Uyon-uyon Hadiluhung Besar $1953 \mathrm{Wawu}$ /on August 10, 2020. This study tries to examine whether social media has positive or negative impacts on traditional dance revitalization in this hyperreality-post truth era.

\section{LITERATURE REVIEW}

\subsection{Hiperrealitas (Hyperreality)}

The post-modern era began in the 1960 s, when the consumption factor became dominant. As the society 
became more consuming, the commodity value which consists of use-value and exchange-value is replaced by sign-value and symbol-value [5]. These new values emphasize the symbolic meaning contained in products, such as lifestyle, prestige, luxury, and status, rather than their benefits. People tend to buy something they do not really need due to the desire to consume which is developed by advertisements. This phenomenon is known as hyperreality. It is characterized by artificial realities which appear more real and have a more impact than reality.

It is true that this world is full of artificial realities. There are terms proposed by Jean Baudrillard for this kind of condition i.e., simulakras/simulacrums and simulations. Simulakra is a reality space filled with the process of reduplication and recycling of various life fragments (in the form of a chaotic commodity of images, facts, signs, and codes), in the same space and time dimension. Simulakra has no reference because it is the duplication of duplication, so the difference between the duplication and the original is blurred. In this situation, we can no longer differentiate whether something is original or fake, production or reproduction, object or subject, and signified or signifier. In this simulation era, reality no longer has an existence, and it has merged into one with signs, images, and reproduction models [5]. Objects no longer have a social reference as they are made over fantasy, fiction, hallucinations, and memory so that they are not distinctive.

\subsection{Post-truth}

The term "post-truth" was first used in 2016 when Brexit phenomenon first appeared, and the moment of President of the United States was elected. Post-truth is a matter that is relevant or indicates a situation in which objective facts have less influence on the creation of public opinion than appeals to emotions and personal beliefs [4]. The post-truth era is a "socio-political climate in which objectivity and rationality allow emotions or desires to side with beliefs even though the facts show different things" [1]. What touches our hearts is believed more than real facts. This post-truth characteristic is marked by the development of social media and hoaxes (fake news). Information from social media spreads fast and is more trusted by today's society, even though the truth of the information is not valid. The phenomenon of hoaxes that undermine the objectivity and credibility of information cannot be separated from new ways to access public opinion.

Social media, such as WhatsApp, Facebook, personal blogs, SnapChat, Twitter, and YouTube are the media where people can freely comment on something [1]. In social media, some information is changed in that people are confused. People now live in a virtual world that is created to be more real and attractive than the reality. The issue of truth and morals is no longer important because people focus on fulfilling their desire rather than looking for objectivity. This era is characterized by the loss of originality, authenticity, and tradition.

\subsection{Revitalization}

Revitalization is the concept of "reviving" traditional arts considered ancient or endangered today. The term revitalization originally referred to architectural or art building, including ancient buildings, historical monuments such as temples, shrines, places of pilgrimage, and so on [8]. Relics that are considered cultural heritage need to be preserved, protected, and even developed so that they are not. Therefore, revitalization is considered able to save cultural heritage objects. This revitalization concept also applies to traditional art performances.

Traditional arts need to be preserved because people are no longer attracted to this kind of art. This preservation is very important because traditional art is not just a culture, but something that has historical values or philosophical meanings. Revitalization is a process of preserving, protecting, developing, and maintaining. It also involves a creative process. Preserving means reviving, so the thing being preserved is not damaged, extinct, or lost. The revitalization process should reach a sustainable level or re-existing. In order to be sustainable in the process of preservation, traditional arts must be developed. The word "develop" in the process of preservation is in terms of both quality and quantity. In terms of quality, the form of the traditional arts should be refined. Them, in terms of quantity, the arts should be published to make them more popular. Refining arts also mean an effort to improve the forms of the arts.

The revitalization process will not work if the arts do not change their forms. It does not literally mean changing the forms but developing its' quality. For example, if someone wants to develop the quality of a building that has a certain color tone, he/she should use the color to match the original color. Another example is when changing a pillar in a pendapa building in Java, the pillar quality must be the same as the original. The transformation process is sometimes difficult to be done because the materials are not available or are no longer produced. Therefore, the process of revitalization should focus on the improvement of quality. After being preserved and developed, an artwork should be sustainable, so it needs to be maintained continuously. Thus, maintenance is better understood as managing or organizing. The revitalization also includes a creative process because there are efforts to renew the forms that can give "new life". Creativity can be defined as the ability to find or create new solutions. In the 
revitalization of traditional arts, the concepts of "creativity" and "inventivity" are intertwined with "ethical" considerations, which is to pay attention to the "appropriateness of the existing traditional culture.

\subsection{Tari Srimpi Muncar}

Srimpi Muncar dance is the classical dance of the Yogyakarta Palace [3]. It is the work of Yasan Dalem (work) of Sri Sultan Hamengku Buwono VI (18551877). It was first created in 1857 and refined in the era of Sri Sultan Hamengku Buwono VIII (19211939). The word 'Muncar' means to shine. The dancers of Srimpi Muncar dance brought stories from Kagungan Dalem Serat Menak-the battle of Dewi Adaninggar (Chinese daughter) from Tartaripura with Dewi Kelaswara from Kelan. Serat Menak is a Javanese epic from Persian Islamic touch, it was inspired by the heroism of the Prophet Muhammad's uncle, Amir Hamza. Because of this Chinese female figure, Srimpi Muncar is often referred to as Srimpi Cina.

In the dance performance, the two figures are distinguished in the variety of movements, clothing, and make-up. Both of them carried weapons, namely kris (Javanese blade) for Dewi Kelaswara and cundrik (small Javanese blade) for Dewi Adaninggar. In the battle scene, Dewi Adaninggar and Dewi Kelaswara fight for the love of Wong Agung Jayengrana. The two daughters who have the same strength fight each other until finally Dewi Kelaswara wins the battle. Srimpi Muncar dance has a special variety of movements called sojah showing that Dewi Adaninggar died in battle. This movement is performed in a bowed position like prostrating in front of Dewi Kelaswara. Srimpi Muncar dance was once performed to celebrate the wedding ceremony of Sri Sultan Hamengku Buwana VII daughter, GKR Timur, with KGPAA Mangkunegoro VII on September 6, 1920. This Beksan is quite popular to be taught in women dance or royal dance outside the palace, in The Beksa Wirama Kridha Art School in 1918.

\section{RESEARCH METHOD}

The method used in this research is a qualitative research method with a phenomenological approach. The qualitative research method is used to examine the condition of a natural object, (as opposed to an experiment) in which the researcher is the key instrument. The data analysis techniques used was triangulation (combination), data analysis was inductive, and the results of qualitative research emphasize meaning rather than generalization [6]. Phenomenological research focuses on something that is experienced by an individual. It is intentional as it describes the relationship between processes that occur in reality and objects that are concerned with that process. Phenomenology provides a reflection on direct experience or reflection on symptoms/phenomena. The focus of phenomenology is not on particular experiences, but on the structure of real experience, namely objective reality that manifests in the subjective experience of individuals. Phenomenology focuses on the subjective meaning of the objective reality of people who live their daily activities [2].

In this study, the documentation was in the form of comments given by the public to the social media accounts. Then secondary data was obtained through interviews with a Yogyakartan classical dance expert who has his dance association. The interview technique used is character interview, where the interviewee is selected based on their expertise in the field being researched [7]. Other secondary data was the result of consultations with the researcher's supervisor who is also an expert in Yogyakartan classical dance.

The data were analyzed through three stages, namely data reduction, data presentation, and conclusion drawing. Data reduction was done by summarizing, selecting the main things, focusing on important things, looking for themes and patterns as well as removing unnecessary ones in that providing a clearer concept being researched [7]. The data were then presented in the form of narrative text and "Matrix" to help organize and arrange the patterns [7]. The final step in data analysis consisted of conclusion drawing and verification [7]. In this study, the triangulation technique was used to test the reliability of the data. This was done by checking data from the same source with different techniques. For example, data obtained by interviews were compared to data collected through observation, documentation, or questionnaire [6].

\section{RESULT}

Srimpi Muncar dance has not been performed since 2014. As ordered by dhawuh, this dance was performed at Uyon-uyon Hadiluhung Besar event on 1953 Wawu/August 10, 2020. Srimpi Muncar dance was revitalized based on what is recorded in Kagungan Dalem, or Bedhaya and Srimpi books in the Yogyakarta Palace Library. What makes the dance different is the duration? In the past, the duration was over one hour, but it is now shortened into 40 minutes for Uyon-uyon Hadiluhung. The costumes used are gladhi (practice) costumes with accessories and colored kebayas to enhance your appearance.

On social media, the show was opened by showing an announcement video and a video showing how the dancers practiced the dance accompanied by Muncar music. The videos were quickly shared on social media via a retweet and repost. The 
explanation of the Uyon-uyon Hadiluhung event as well as complete information about Srimpi Muncar dance were published on the Ngayogyakarta Hadiningrat Karaton website. In addition, the Yogyakarta Keraton YouTube account uploaded 5 videos in the form of vlogs hosted by young courtiers as follows: (1) preparation of Uyon-uyon Hadiluhung Keraton Yogyakarta during the COVID-19 Pandemic, (2) preparation of Uyon-uyon Hadiluhung: Strong Women behid Srimpi Muncar, (3) preparation of uyon-uyon Hadiluhung: Behind Srimpi Muncar, (4) preparation of Uyon-uyon Hadiluhung: Explanation about Gendhing and the meaning of Srimpi Muncar, and (5) Srimpi Muncar perfomance by KHP Kridhomardowo.

These five vlogs are accompanied by a virtual tour of the Yogyakarta Palace. Videos (1) and (5) show the preparation before and on the day of the event which was conducted based on health regulation. Video (2) shows how the story of Serat Menak as told by an abdi dalem (Royal servant) and wayang golek (Sundanese wayang) performance. Then in video (3), the abdi dalem conducted interviews with Srimpi Muncar dancers. They asked about the costumes and differences between the two types of weapons, namely the keris worn by Dewi Kelaswara and the cundrik worn by Dewi Adaninggar. This visual explanation helped us understand Serat Menak characters, as well as the costumes and weapons used. Based on the comments given to the 5 vlog videos, praises were given to the vlog hosts. As millennial generation, the young abdi dalem (hosts) seemed dedicated in preserving their culture and tradition. Uyon-uyon Hadiluhung live stream from the YouTube was fully broadcasted, from the beginning to the end of the event. The abdi dalem and performers obeyed the health regulation because they wore face masks and face shields.

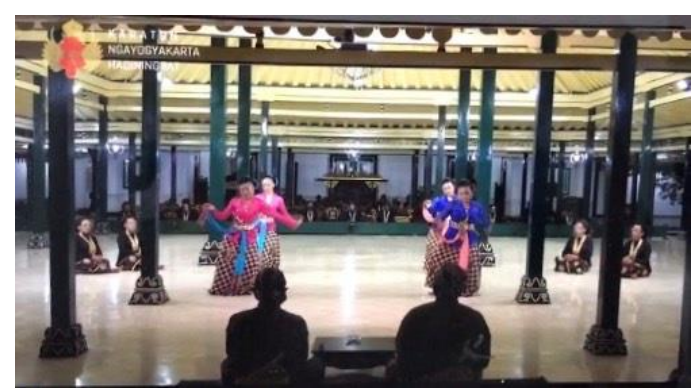

Figure 1. Live streaming of Srimpi Muncar dance

Through Yogyakarta Palace social media, it is proven that handihulung art will not stop as it will be preserved and developed even during this COVID-19 pandemic.

\section{DISCUSSION}

Berdasarkan hasil studi dokumentasi, wawancara,

Based on the results of documentation, interviews, and consultations, Srimpi Muncar dance shown in social media through live streaming is not a hyperreality, because its impact is positive. In the live steaming, nothing is exaggerated or fabricated with false information as seen in advertisements. Srimpi Muncar dance is fully broadcasted, so that people from all over the world can watch the dance performance. Live streaming is a new way to preserve traditional arts during a pandemic. The positive impact of social media is better known in society. The palace acknowledges that using social media to promote traditions is something prohibited because it is performed in the palace area.

The researchers had watched Uyon-uyon Hadiluhung several times at the Yogyakarta Palace before the pandemic. They also watched the Uyonuyon Hadiluhung live stream during the pandemic. Srimpi Muncar dance shown through social media is a positive thing. This dance, which was not performed for a long time, but is now back to its original state through the latest technology. The comments given on social media were also very positive. Some of the comments were praises that showed longing for the city of Yogyakarta, the pride of Javanese culture, enthusiasm for preserving Javanese culture, and motivation to keep strong in facing the Covid-19 outbreak. Through social media, the people in Indonesia and abroad expressed their appreciation to the palace for broadcasting the event online. The Yogyakarta Palace social media account played the main role. The show does not indicate any hyperreality where truth, lies, reality, and illusion are fused into one. The benefits of social media are shown in the traditional live streaming show.

\section{CONCLUSION}

The virtual world has both positive and negative impacts. Some are called hyperreality and some are not. In the post-truth era, the negative impacts tend to stand out. Thus, hoaxes (fake news), false information in advertisements, and hyperreality create a simulakra situation where people are no longer aware of the difference between the manipulated world and reality. Meanwhile, the positive impact can be seen in the way Yogyakarta Palace show their event through live streaming. The advancement of technology enables us to enjoy the dance performance from home. Performing online through social media in a positive sense is based on accurate factual data. Srimpi Muncar dance performance requires should follow strict rules. This art performance must be carried out in accordance with what is ordered by the Sultan. Moreover, the dance and accompaniment must be in accordance with what is recorded in the Kagungan Dalem.

Although advertising through social media does not require accurate facts or data because the quality is not important, all dancers and musical 
accompaniment should be highly qualified. According to Hidayat [5], in the perspective of postmodernism, advertising is a representation of various simulated community characters that are mixed up between images, signs, symbols, idioms, and codes of various cultures [5]. Postmodern advertising is no longer concerned with the role of providing information about the value and quality of the products it offers. On the contrary, the Yogyakarta Palace social media accounts, i.e., YouTube, Facebook, Instagram, Twitter, and the Ngayogyakarta Hadiningrat Karaton website, have contributed greatly to the revitalization of Srimpi Muncar dance. Social media is a new way to revitalize traditional art performances through this pandemic situation. Traditional arts will not be left behind due to technology as technology will be an aid for developing traditional arts in this day and age.

\section{REFERENCES}

[1] Suwignyo, Agus, ed. Post-truth dan (anti) pluralisme: forum mangunwijaya 2018 [Posttruth and (anti) pluralism: the 2018 mangunwijaya forum]. Penerbit Buku Kompas, 2019.

[2] Hamzah, Amir. Metode Penelitian Kualitatif: Rekontruksi Pemikiran Dasar Serta Contoh Penerapan Pada Ilmu Pendidikan, Sosial Dan Humaniora [Qualitative Research Methods: Reconstruction of Basic Thought and Examples of Application in Educational, Social and Humanities Sciences]. Batu: Literasi Nusantara (2018).

[3] Suprihono, Arif Eko. Tari Srimpi: Ekspresi Budaya Para Bangsawan Jawa [Srimpi Dance: Cultural Expressions of Javanese Nobles], Departemen Pendidikan dan Kebudayaan, 1994/1995.

[4] McIntyre, Lee. Post-truth. MIt Press, 2018. DOI: https://doi.org/10.7551/mitpress/11483.001.0001

[5] Aginta Hidayat, Medhy. Menggugat Modernisme [Challenge Modernism]. Yogyakarta: Jalasutra (2017).

[6] Sugiyono, Prof. Memahami penelitian kualitatif [Understanding the qualitative research]. Bandung: Alfabeta (2005).

[7] Rohidi, Tjetjep Rohendi. Metodologi penelitian seni [Art research methodology]. Semarang: Cipta Prima Nusantara 75 (2011): 116-121.

[8] Hadi, Y. Sumandiyo. Revitalisasi Tari Tradisional [Revitalizing Traditional Dance.]. Dwi-Quantum, 2018. 